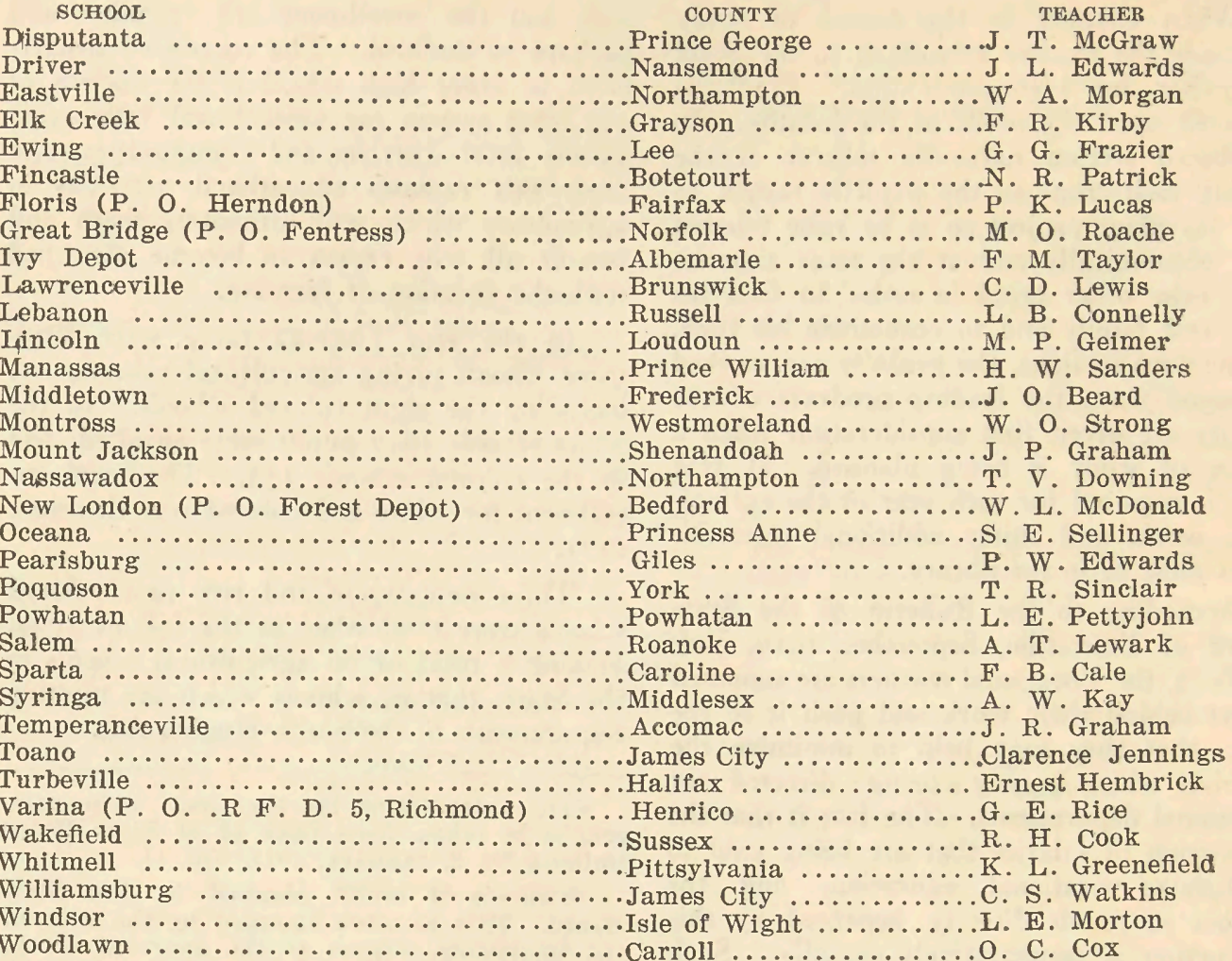

COLORED SCHOOLS
Albemarle Co. Tr. School, Charlottesville, Va..................... P. Burley

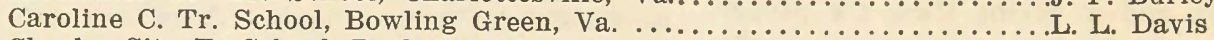 Charles City $\operatorname{Tr}$ School, Ruthville, Va. ........................ A. Oliver

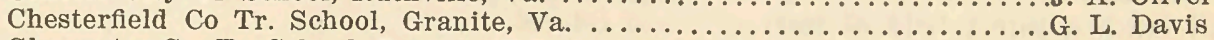

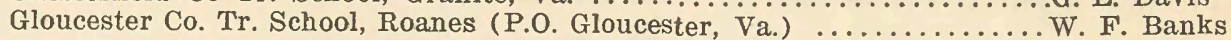 Halifax Co. Tr. School, Halifax, Va. ........................... S. Sykes Middlesex Co. Tr. School, Syringia, Va. .......................... H. St. C. Walker Nottoway Co. Tr. School, Blackstone, Va. ....................... M. Botts Sussex Co. Tr. School, Waverly, Va. .......................... N. Bolling

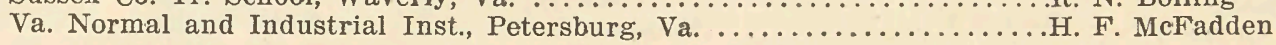

The following bulletins will be of great help to agricultural teachers: Bulletin No. 16, Agricultural Training, Department of Agriculture, Richmond, Va.; Farmers' Bulletin 104I, U. S. Department of Agriculture, Washington, D. C.; Bulletin No. 10 of the State of Missouri for Vocational Education, September 1921; Bulletin No. 2, Vocational Agriculture State Board of Education, Richmond, Va.; Sept. 1922, Bulletin No. I "Agricultural Education and Administration," Washington, D. C.; Dec. Bulletin No. 5, Volume XV of Virginia Polytechnic Institute, Blacksburg, Va.

The following books:
Benson and Betts-Agriculture, BobbsMerrill; Davis-How to teach Agriculture, Lippincott; Robeson-Lyon's Soils, Macmillan Company.-Ida SAville.

\section{WHAT DO INTELLIGENCE TESTS MEASURE}

Are intelligence tests worthless? What is meant by mental age? Is it true that the average mental age of the American people is 14 , and if so what does this mean? Different people will probably answer these questions in different ways, largely owing to 
the fact that their real purpose and significance is not understood. In the September issue of Hygeia Mr. L. L. Thurstone, of the Bureau of Public Personnel Administration in Washington, clearly and carefully analyzes the meaning of the tests and their value. $\mathrm{He}$ says: "An intelligence test is intended to measure, more or less roughly only, the degree of mentality or intelligence of the candidate."

A school examination is intended to measure how much we know, how much we have learned from a course of instruction or from experience. The intelligence test is intended to measure, not how much we have already learned, but how good a mind we have, irrespective of our education. For this reason many of the tests often seem to be foolish and too easy. In many of them the person examined is required to learn something, and he is graded on the speed and accuracy with which he does so. For the same reason, the method of marking is made objective, that is to say the answers must conform to certain standards that have been found by experience to represent certain stages in mental activity, and the credit given does not depend on the opinion of the person who marks them.

"One of the most common misunderstandings about intelligence tests concerns the idea expressed by the term mental age. We hear statements to the effect that the general population of the United States is only fourteen years old mentally, and that it is a very terrible fact. The psychologists are largely to blame, I believe, for this absurd misinterpretation." The fact of the matter is that the tests by which mental age is measured do not go above fifteen years and, since there must always be some people with less intelligence, the general average is bound to be below fifteen. Mental development beyond the years of early adolescence consists in learning to use the facts that we have acquired and new methods and tricks of solving problems as well as control over emotions and volition. It is these properties that spell the difference between the mind of of the adult and that of the child. These qualities are not taken into consideration in the intelligence tests in ordinary use.-Collier's National Weekly.

\section{PHYSICAL EDUCATION-A NEW PLAN}

"Good health, good sports, and clean habits."

That Physical Education has been accepted as one of the first and foremost educational processes is an already established fact. The other two, mental and moral, are no more or less important. They are, each one, equally dependent on the other and, therefore, must be treated with equal consideration.

The mental and moral sides have been theorized and experimented on time and time again, but not until the present day has physical education come into its own since the old Spartan martial routine. And now that it has been recognized, the big problem of scientific organization arises. Its place in the school curriculum of the last several years has been, mainly, five or ten minutes of exercises here and there through the day's program-with no apparent objective to the pupils, and with the teacher reading, half-heartedly, directions from a circular paper not even thought about until time for the exercise. But as all educational aims, theories and principles are changing, so must this change and the work now ahead of us is to find the "psychological approach" to this important phase of education.

A recent experiment in "psychological approach" has been the Dalton Plan. This plan has come nearer than any prevous to the realization of "equalization of opportunity" for all students. It upholds and allows for all the educational aims-mind set to a purpose, will to learn and sustained attention. It lacks, though, sufficient provision for oral recitation when applied to subjects like arithmetic, English, geography, etc., but when applied to physical education works, this does not figure. It gives an opportunity for the strivenfor aims, ideals, values, and results. It includes threefold benefits-physical, mental and moral.

According to the plan, the physical advantages of the athlete are: he abstains from liquor and tobacco, he is carefully and balancedly dieted, he keeeps his body vigorous and clean, and he builds his ideals on wholesome outdoor ideals.

Mentally, he must work out reasons for 